\title{
Acceptance of M-Pesa Service and its Effect on Performance of Small and Micro-Businesses in Kenya
}

\author{
Ann Kalei, (PhD) \\ School of Business Administration \\ Presbyterian University of East Africa \\ P.O Box 387-00902 Kikuyu Kenya \\ Mumbuawambua@yahoo.com
}

\author{
Hannah Wanjiku Wambugu (PhD) \\ School of Business Administration and Economics \\ Kirinyaga University College \\ P.O Box 143-10300, Kerugoya, Kenya \\ wambuguhannah@yahoo.com
}

\section{Peter Githae Muturi (MBA) \\ School of Business Administration \\ Presbyterian University of East Africa \\ P.O Box 387-00902, Kikuyu, Kenya}

\begin{abstract}
A lot of research has been done on the effect of mobile money on efficiency of and outreach of micro-finance loans in developing countries. Yet to date, there has been no quantitative test to show the factors driving the acceptance of mobile- money service, and whether the level of acceptance has any significant effect on the performance of small and micro-businesses in Kenya. This study investigated factors determining the acceptance of M-PESA service and the effect of M-pesa Service on small and micro-businesses in Kenya. It further investigated the challenges facing M-PESA users in Kenya. The study adopted a survey and case study design on a sample of 1230 small and micro-business operators in Limuru town in Kenya. ANOVA tests was used to show whether there are differences in average acceptance of the M-PESA service among consumers who had different views regarding: perceived ease of use, social influence, facilitating conditions and trust i.e security of the service. Regression analysis was used to show the actual effect of the acceptance of M-Pesa on small and micro-business performance. Results indicated that, there is a significant difference in acceptance of M-pesa by traders who had: reported different perceived ease of use, social influence, facilitating conditions by the provider and security of the system when transferring money. After controlling for the factors that influences performance, regression results indicated that, acceptance of $M$-pesa had positive and significant effect on the performance. Security of money transactions, sending money to the wrong persons and lack of electronic money float were identified as challenges facing M-PESA service users and agents in Kenya. The knowledge generated in this study is important to the business community in Kenya and Mobile money service providers in Kenya. A conclusion can be reached that M-Pesa is an intervention in business world that has contributed to improvement in performance of small and micro-business in Kenya. The recommendation is that microbusinesses should embrace mobile banking, for it is an intervention that will go a long way in improving lives for Kenyans.
\end{abstract}

Keywords: M-banking, M-PESA, M-PESA acceptance, perceived ease of use, social influence, facilitating conditions and security of the system.

\section{BACKGROUND OF THE STUDY}

One of the latest innovations in mobile telecommunications is the increasing use of mobile technology for the cost-effective delivery of financial services to the low-income households. Developing economies, where access to finance remains limited, particularly in rural areas, mobile devices have entered the homes and daily lives of millions. This has facilitated extension of financial services to the un-banked people especially the ones belonging to the low income strata of the society in a cost effective manner. According to Perlman (2010), this is viewed as a big step towards poverty alleviation. The mobile phone has the potential to fill the gap in the financial infrastructure. Indeed, it is already being used in various countries, the best known of which is Kenya which has nearly 7 million or $38 \%$ of its cellular customers using a mobile money system (Economist 2009c)

Mobile Money is simply defined as the money that can be accessed and used via mobile phone (Jenkins, 2008). The term m-banking, refer to a set of applications that enable people to use their 
mobile telephones to manipulate their bank accounts, store value in an account linked to their handsets, transfer funds or even access credit or insurance products. The first targets for these applications were consumers in the developed world. By complementing services offered by the banking system, such as cheque books, automated teller machines (ATMs), voicemail/landline interfaces, smart cards, point-of-sale networks, and internet resources, the mobile platform offers a convenient additional method for managing money without handling cash ( Karjaluoto H, 2002).For users in the developing world, the appeal of these m-payments systems may be less about convenience and more about accessibility and affordability (Cracknell, 2004; info DEV, 2006). This is done through M-PESA which is a small-value electronic payment and store of value system that is accessible from ordinary mobile phones to customers registered at authorized M-PESA retail outlets.

Limuru town is in Kiambu County, central Kenya with a population of about 4800 people. Limuru is a town located on the eastern edge of the Great Rift Valley about 30km North-West from Nairobi the capital city of Kenya. Limuru residents rely mostly on farming and BATA shoe factory for employment. Early in the British colonial period Europeans settled in the area due to its proximity to Nairobi, the railway line, its fertile land and pleasant weather. Most of the area of Limuru is what was previously known as "the white highlands", a rich agricultural land just south of the equator. Limuru has an average temperature range about of $28{ }^{\circ} \mathrm{C}$ year round, and it is widely-known in Kenya for the large amounts of tea it produces. The influx of workers in the tea farms and the factories available has led to flourishing of many micro businesses in the town to meet the needs of these workers who are mainly low income earners. The availability of these micro businesses creates a firm foundation upon which this study can be undertaken.

\section{Statement of The Problem}

According to Central Bureau Statistics, Kenya has over 7 Million people employed in the informal sector, which has translated to about 19\% of the total Kenyan population (CBS 2005). This sector has continuously experienced growth, and becoming a key sector in the economy of the country, creating most of the new jobs in Kenya. It has resonated to be a key pillar towards poverty alleviation as well as raising the standards of living of the people. According to Malick (2004) Kenya's informal sector constitutes $98 \%$ of all businesses in the country, absorbing a high population of school, college and university leavers. According to the Baseline Survey of 2006, the number has grown to 1.8million from 910,000 in 1993.

According to Haans (2001) the informal sector is segmented into three. The smallest segment is the Income-Generating Activities (IGAs) which is the most predominant type of informal businesses. It consist seasonal trading and hawking, keeping domestic animals, and many traditional craft activities, especially in rural areas. The second segment of the micro-enterprises has businesses that are slightly bigger than IGAs, which includes small shops, metal working, carpentry, tailoring, and various forms of repair services. They operate with a few family workers, apprentices with one or a few permanent workers. Their technology is a mix of traditional and modern methods. Their market is limited since they serve local and nearby markets. They are found in larger villages, rural towns and regional centers. The third segment comprises the Small enterprises (SMEs). These are firms with roughly 10 to 20 workers that are at the boundary between formal and informal sector. They use non-traditional technology in the production process. Their products and services range from simple to complex and similarly span a range of consumer types. They are usually registered with the local government and hence they pay taxes. SEs are more urban than rural-based and good examples of small enterprises include, saw mills, garment assembly, motorized transport, building \& construction and medium-scale industrial agro-processing.

The emergence of M-PESA, a text messaging service (SMS) provide the solution to small businesses banking needs and majority of the Kenyan population. This is because the majority of Kenyans don't hold bank accounts but they do have the services of a mobile phone, hence they could settle bills by building up credit on the mobile phones and then sending a text (SMS) to make a payment. The leading mobile service providers in Kenya have introduced some money transfer services whose objective is to enable Kenyans to make 'micro payments' using their mobile phones. This saves time that could have been spent at the long queues in the bank. The service enables subscribers to use their mobile phones to carry out transactions such as pay for goods and services, pay utility bills, send to and receive money from friends and relatives, withdraw cash for their use, top up their own airtime account or top up someone else's account and manage their own accounts. The use of mobile 
payment technology requires basic knowledge to operate and hence majority of micro business operators are able to employ this technology in the daily business operations. These services are supposed to provide an e-commerce platform of choice in a country where credit cards have struggled to reach most the population without the bank accounts.

The government has encouraged the Kenyan population to join the information superhighways, to make them competitive and have a global reach, penetrate more markets and access information from different sources. As a result Small and Medium Enterprises (SME's) in the less developed world are increasingly deploying the use of mobile payments to enhance the quality of their services and increase growth. The rate of transformation in the SME sector has speeded up with more small businesses realizing the potential of using the mobile payments in service delivery. However, there are only a handful of studies focusing directly on the effect of M-money transfer on the performance of small and medium business sector in Kenya. This study therefore, investigates the acceptance of M-PESA service and the effect of this service on the performance of SME's in Kenya.

\section{OBJECTIVES OF THE STUDY}

The general objective of the study was to investigate the use of M-PESA service by small and micro enterprises in Kenya. The study was guided by the following specific objectives.

- To identify the determinant of the acceptance of mobile money transfer

- To determine whether acceptance of M-PESA service has significant effect on the performance of small and micro-business in Kenya.

- To establish the major constraints facing micro- business owners when using M-PESA) service

The findings of this research would be useful to the Mobile Network Operators (MNOs) in creating services that consumers want to use, or help them discover why potential users avoid using the existing system. Small business owners can use the study to educate themselves on the reason why mbanking would be important to them. Finally, scholars and other researchers may wish to use the findings of this research to carry out further research.

\section{Theoretical Literature}

\subsection{Perceived Ease of use}

This is the degree to which a person believes that using a particular system will be free of effort'(Davis, 1989). In mobile money transfer, it includes registration procedures, ease of use of the payment procedure, easy access to customer services, minimal steps required to make a payment, appropriate screen size and input capabilities. Also, the availability of the mobile money transfer agents will increase the perceived ease of use. Furthermore, it should be accessible on mobile phones with the most basic features and software. Prior researches have concluded that perceived ease to use is a key determinant to consumer behavioral intentions (Venkatesh \& Davis, 1996, 2000; Venkatesh \& Morris, 2003, Pousttchi \& Wiedemann, 2005). In order to prevent the "under-used" system problem, Mobile money transfer system must be both easy to learn and easy to use.

\subsection{Social Influence}

Social influence is defined as the degree to which an individual perceives that important others believe he or she should use the new system. The working members of the society, usually located in the urban areas, needs an inexpensive but reliable method of sending money to their unemployed relatives back in the villages (Manica and Vescovi, 2009). A large percentage of the old, the poor, the unemployed and young adults depend on the employed relatives for financial support. The early adopters of mobile money are young urban workers who would want to transfer money to their relatives living in rural areas. However, in order to receive the money, the receiver, typically an illiterate resident in rural Kenya, also need to have an M-PESA account. Normally, these illiterate rural residents are considered the laggards, and are expected to be the last adopters of any new technology. However, in order to cash the money, they must be registered and finally they end up joining the technology band wagon.

\subsection{Facilitating Conditions}

Facilitating conditions are defined as the degree to which an individual believes that organizational and technical infrastructure exists to support use of the system. The extent to which the mobile 
payment usage would be adopted largely depends on whether there is an enabling environment (Porteous, 2006). According to Porteous (2009) an enabling environment is a set of conditions which promote a sustainable trajectory of market development. Of particular interest are the environments in which widespread access is likely. M-PESA has widespread access and requires an enabling environment to enhance the success of its consumers. The micro businesses are spread throughout the country with huge clusters in the market areas and near shopping centers. This enables them to easily access the M-PESA service providers for registration and to make cash deposits into their accounts. The mobile payment providers' agents are well distributed and easily accessible to the micro business owners for support of their services in Kenya. The service provider together with the regulatory authority are responsible for the creation of this enabling environment. According to Omwasa, (2009) the transaction costs of sending money through the mobile payment technology are lower than those of banks and money transfer companies. The cost of a payment transaction has a direct effect on consumer adoption if the cost is passed on to customers (Mallat, 2007). Transaction costs should be low to make the total cost of the transaction competitive. The cost of the mobile payments should be affordable to most of the micro business operators and far below what the banks normally charge for their bank transactions. M-PESA pricing is made transparent and predictable for users. There are no customer charges for the SMSs that deliver the service, and instead fees are applied to the actual customer who initiated transactions. All customer fees are subtracted from the customer's account, and outlets cannot charge any direct fees. Thus, outlets collect their commissions from Safaricom rather than from customers. This reduces the potential for agent abuses. Customer fees are uniform nationwide, and they are prominently posted in all outlet locations in the poster for all to view. M-PESA chose to specify its fees in fixed currency terms rather than as a percentage of the transaction. This makes it easier for customers to understand the precise cost of each transaction and helps them think of the fee in terms of the transaction's absolute value. It also helps them compare the transaction cost against alternatives such as the matatu fare plus travel time. It is worthy to note that M-PESA has maintained the same pricing for transactions in its first three years, despite the significant inflation experienced during the period. In her field research, Olga Morawczynski finds that sending KShs 1,000 through M-PESA is $27 \%$ cheaper than the post office's Posta Pay, and 68\% cheaper than sending it via a bus company. Morawczynski and Pickens (2009)

\subsection{Trust/Security}

Mobile phone balances may seem low, but this proves that there is storage which can be perceived as acceptance of deposits (Njenga, 2009). This is a significant indication of the high value placed on the convenience associated with the use of the mobile payment services. According to Omwansa (2009) a lost or stolen mobile phone does not mean catastrophe as no one can access an M-PESA account without a correct personal identification number (PIN). He further explains that in a country where majority of people have no bank accounts, M-PESA provides both convenience and safety. People walk around with their virtual money knowing they can withdraw cash any time at a minimal fee. Trust/security is a facilitating condition which is created by the enabling environment. Once trust is created in mobile money transfer system, the conservative members of the society who are risk averse join the technology bandwagon due to lowered risks creating a "tornado effect" in the actual usage of the service.

Many theories have been used for the last two decades to explain possible consumer behavior on adoption and acceptance patterns of new technologies and innovations. They include: Davies' (1989) technology acceptance model In Information Systems literature by Roger's (1991), innovation diffusion theory (IDT) by Davies' (1989), technology acceptance model by Davis (1989), the theory of planned behaviour by Azjen (1977) and the unified theory of acceptance and use of technology (UTAUT) by Venkatesh et al. (2003). Several researchers have sought to develop constructs that affect consumers' behaviour when deciding on the adoption of mobile services by applying these existing information system theories and models (Wu and Wang, 2005; Hung et al, 2004; Bouwman et al, 2007). This research will mix the Technology Acceptance Model (TAM) and the Unified Theory of Acceptance and use of Technology (UTAUT) to explain how M-PESA technology has been adopted in Kenya. Analyzing M-PESA using the above theories, one would know whether M-Pesa has significant on the SMEs performance in Kenya. This is the only way to establish whether it represents a true innovation, introducing a significant departure from the traditional ways of paying for goods/services purchased. 


\section{Conceptual Framework}

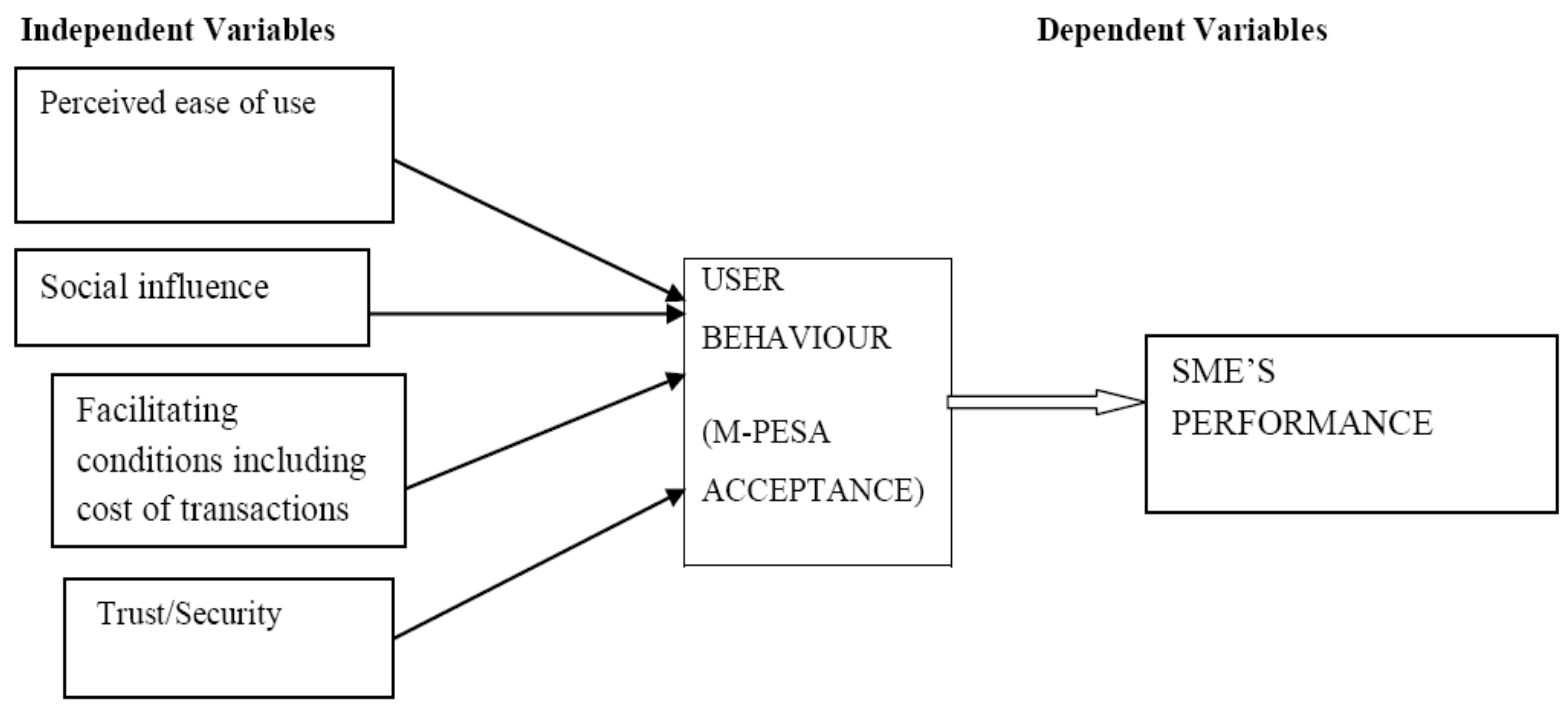

\section{RESEARCH METHODOLOGY}

The study adopted a survey design, and the population of interest comprised owners and staff working in the 7 million small and micro enterprises in Kenya. A sample of 1230 respondents was used, and was determined using the formula proposed by Saunders et al, (2007 p.g 214): $\mathrm{n}^{a}=\frac{n X 100}{r e \%}$, where: $\mathrm{n}^{a}=$ the actual sample size required, $\mathrm{n}=$ minimum (or adjusted minimum) sample size, $\mathrm{re} \%=$ the estimated response rate expressed as a percentage. In line with many studies in business management, a level of confidence of ninety five percent, which corresponded with $\mathrm{z}=1.96$ was assumed. Assuming that $80 \%$ of Kenyan business are small scale in size while only $20 \%$ are large in size. Thus, the minimum sample size was computed as follows: $\mathrm{n}=\mathrm{p} \% \times \mathrm{q} \% \times\left(\frac{z}{e \%}\right)^{2}$, where: $n=$ minimum sample size required, $p \%=$ proportion belonging to the specified category, $q \%=$ proportion not belonging to the specified category, $z=z$ value corresponding to the level of confidence required while $\mathrm{e} \%=$ margin of error required. Thus, $\mathrm{n}=20 \times 80 \times\left(\frac{1.96}{5}\right)^{2}$ which was equal to 246.4. This had to be adjusted to 246.38 according to the target population of 3,424,000 using the formula provided by Saunders et al, (2007 p.g 586) where, $\mathrm{n}^{\prime}=\frac{n}{1+\left(\frac{n}{N}\right)}$. In this formula, $\mathrm{n}^{\prime}=$ the adjusted minimum sample size, $\mathrm{n}=$ the minimum sample size, and $\mathrm{N}=$ the target population. The computed adjusted minimum sample was substituted into the formula used to determine the actual sample size in the previous page. Expecting a response rate of 20 percent, the actual sample size of 1230 respondents was arrived at. Questionnaires were distributed to randomly selected sample of micro- business enterprises within the town. The questionnaire included both open-ended and closed questions. The open ended questions encouraged the respondents to express their views while the closed questions will gave the respondents a chance to express their opinions and give the researcher a chance to get specific responses towards the research. The questions were simplified to enable the respondents complete them with ease. The questionnaire included the construct items adapted from previous studies (Davis, 1989; Venkatesh and Bala, 2008) modified to meet the needs of the study.

Data was analyzed using quantitative statistics. To address objectives (i) ANOVA test done to indicate whether there was any difference between means while regression analysis was used to show whether the acceptance of the M-PESA services has significance effect on the firm performance. The explanatory variables are: $X_{1}=$ perceived ease of use, $X_{2}=$ Social influence, $X_{3}=$ Facilitating means, $X_{4}=$ Trust/security of transactions 
Ann Kalei et al.

The identified variables for the ANOVA analysis are specified as follows:

\begin{tabular}{|l|l|l|}
\hline Independent Variable & How obtained & Description \\
\hline M-pesa acceptance & $\begin{array}{l}\text { Respondents rated their acceptance using a } \\
\text { scale using a scale of 1-5 } \\
\text { Respondents rated the degree to which } \\
\text { they believed that using m-pesa system } \\
\text { helped him/her to attain gains in the } \\
\text { execution of his duties. }\end{array}$ & $\begin{array}{l}\text { Acceptance=1 if } \\
\text { acceptance=0 if low } \\
\text { Perceived as easy to use =1 if high } \\
\text { and Perceived as easy to use =0 if } \\
\text { low }\end{array}$ \\
\hline$X_{2}$ Social influence & $\begin{array}{l}\text { Respondents indicated whether they were } \\
\text { socially influenced or not }\end{array}$ & $\begin{array}{l}\text { Socially influenced =1 if influenced } \\
\text { and socially influenced =0 if not } \\
\text { influenced }\end{array}$ \\
\hline$X_{3}$ Facilitating & $\begin{array}{l}\text { Respondents rated the Facilitating means } \\
\text { means conditions using (likert scale of 1-7) }\end{array}$ & $\begin{array}{l}\text { Facilitating means conditions }=1 \\
\text { good and facilitating conditions }=0 \\
\text { if bad }\end{array}$ \\
\hline$X_{4}$ Trust/security & $\begin{array}{l}\text { Respondents rated the security of M-PESA } \\
\text { transactions }\end{array}$ & $\begin{array}{l}\text { Trust/security= 1 if good and } \\
\text { Trust/security=0 } \text { if not good }\end{array}$ \\
\hline
\end{tabular}

Objective (ii) was addressed by use of a regression analysis, which was based on the following equation:

$Y=\alpha_{0}+\alpha_{1} X_{1 i}+\alpha_{2} X_{2 i}+\alpha_{3} X_{3 i}+\alpha_{4} X_{4 i}+\alpha_{5} X_{5 i}+\alpha_{6} X_{6 i}+\alpha_{7} X_{7 i}+u_{i}$

Where: $Y=\mathrm{Y}=$ Annual Sales

$X_{1}=$ acceptance of m-pesa, $X_{2}=$ capital investment $X_{3}$, =years of experience in business, $X_{4}=$ owners education, $X_{5}=$ business location, $X_{6}$, = nature of the business, $X_{7}=$ promotion expenditure

\begin{tabular}{|c|c|c|}
\hline Independent Variable & How obtained & Description \\
\hline Acceptance of M-pesa & $\begin{array}{l}\text { Respondents rated their acceptance of } \mathrm{m} \text { - } \\
\text { pesa }\end{array}$ & $\begin{array}{l}\text { Acceptance }=1 \text { if high and } \\
\text { acceptance }=0 \text { if low }\end{array}$ \\
\hline Capital investment & $\begin{array}{l}\text { Respondents indicated the approximate } \\
\text { amount inested }\end{array}$ & Amount in Kenya Shillings \\
\hline Experience in business & $\begin{array}{l}\text { Respondents indicated the period for } \\
\text { which they have been running the } \\
\text { business }\end{array}$ & Number of years \\
\hline Owners education & $\begin{array}{l}\text { Respondents indicated the number of } \\
\text { years they have spent in school }\end{array}$ & \\
\hline Business location & $\begin{array}{l}\text { Respondents indicated where their } \\
\text { business is located }\end{array}$ & $\begin{array}{l}\text { If town centre }=1 \text { and } 0=\text { not at the } \\
\text { center }\end{array}$ \\
\hline $\begin{array}{l}\text { Nature of the business- } \\
\text { industrial goods }\end{array}$ & $\begin{array}{l}\text { Respondents indicated the nature of } \\
\text { business depending on what was sold. }\end{array}$ & $\begin{array}{l}\text { Consumer goods }=1 \text { and } 0= \\
\text { industrial goods }\end{array}$ \\
\hline Promotion budget & $\begin{array}{l}\text { Respondents approximated the amount } \\
\text { they spend to attract customers }\end{array}$ & Amount in shillings \\
\hline
\end{tabular}

Objective (iii) was addressed by asking the M-PESA users and the agents whether they had challenges when using the service. The questions addressed were related to system failure, security and fraud related activities and facilitation of use by Safari Company, mainly provision of electronic float money to the agents.

\section{Results}

Analysis of Variance

\begin{tabular}{|l|l|l|l|l|l|l|}
\hline & Source & SS & Df & MS & F & P-value \\
\hline Perceived ease of use & Between groups & 617.145 & 1 & 617.145 & 160.97 & 0.000 \\
\hline & Within groups & 473.064 & 1228 & 0.385 & & \\
\hline & Total & 1090.209 & 1229 & & & \\
\hline Social Influence & Between groups & 7.357 & 1 & 7.357 & 9.942 & 0.0130 \\
\hline & Within groups & 909.90 & 1228 & 0.740 & & \\
\hline & Total & 917.257 & 1229 & & & \\
\hline Facilitating Conditions & Between groups & 510.06 & 1 & 510.06 & 1882.14 & 0.000 \\
\hline & Within groups & 333.14 & 1228 & 0.271 & & \\
\hline & Total & 843.2 & 1229 & & & \\
\hline Trust/Security & Between groups & 40.725 & 1 & 40.725 & 81.080 & 0.000 \\
\hline & Within groups & 617.488 & 1228 & 0.50228 & & \\
\hline & Total & 658.213 & 1229 & & & \\
\hline
\end{tabular}


The results for the perceived ease to use were: $F(1,1228)=160.97$ and $p$-value $=0.000$. Thus, there was a significant difference in the acceptance of M-Pesa by traders who reported different degrees of perceived ease of use. Results for social influence were $F(1,1228)=9.942$ and $p$-value $=0.0130$, there was a significant difference in the average acceptance of M-Pesa by traders who reported different degrees of social influence. Results for facilitating means conditions were $F(1,1228)=$ 1882.14 and $\mathrm{p}$-value $=0.000$, an indication that there was a significant difference in the average acceptance of M-Pesa by traders who reported different ratings of facilitating means conditions. There was a significant difference in the average acceptance of M-Pesa by traders who reported different ratings of Trust/Security of the system, $\mathrm{F}(1,1228)=81.080$ and $\mathrm{p}$-value $=0.000$.

\begin{tabular}{|c|c|c|c|c|}
\hline \multicolumn{2}{|l|}{ Linear regression } & \multirow{3}{*}{$\begin{array}{l}\text { No.obs } \\
\mathrm{F}(6,1223) \\
\text { Prob }>\mathrm{F}\end{array}$} & \multirow{3}{*}{$\begin{array}{l}= \\
= \\
=\end{array}$} & \multirow{3}{*}{$\begin{array}{l}1230 \\
312.29 \\
0\end{array}$} \\
\hline & & & & \\
\hline & & & & \\
\hline & & R-squared & $=$ & 0.832 \\
\hline & & Adj R-Squaired & & 0.819 \\
\hline & & Root MSE & $=$ & 0.380 \\
\hline & Coef. & Std.Err & $\mathrm{t}$ & $\begin{array}{ll}\mathrm{P}>\mathrm{t} & {[95 \%]}\end{array}$ \\
\hline Acceptance of M-pesa & 0.198 & 0.0254 & 3.88 & 0.001 \\
\hline Capital investment & 1.271 & 0.047 & 27.28 & 0.000 \\
\hline Experience in business & 0.653 & 0.022 & -29.54 & 0.000 \\
\hline Owners education & 0.266 & 0.023 & 11.63 & 0.000 \\
\hline Business location-town center & 0.140 & 0.031 & 4.72 & 0.000 \\
\hline Nature of the business & 0.108 & 0.036 & 2.81 & 0.005 \\
\hline Promotion budget & 0.113 & 0.030 & 3.767 & 0.000 \\
\hline cons & 1.1003 & 0.0961 & 10.49 & 0.000 \\
\hline
\end{tabular}

The Results indicates that, R-squared is equal to 0.832 while adjusted R-squared is equal to 0.819 . This implies that there is high degree of goodness of fit of the regression model. It also means that over $81 \%$ of variation in the dependent variable (the amount of sales as indicator of business performance) can be explained by the regression model. The $F$ test result was $F(7,1221) 312.29$, with a significance of 0.000 . Consequently, the hypothesis that all regression coefficients in the model are zero is rejected. Therefore, a significant relationship was present between the amount of annual sales and the explanatory variables in the regression model. RMSE which is the square root of the variance of the residuals or the standard deviation of the unexplained variation was 0.380 . This was low given that it is below 0.500, which was an indication that there is high degree of goodness of fit of the regression model. All the explanation variables had positive and significant effect on the performance of the business.

The other area of interest was to investigate the outstanding challenges facing M-PESA and possible solutions. $46.6 \%$ of the respondents indicated that they had no complaints with the M-PESA service. This suggests that almost half of the respondents are satisfied by the service. However, the rest made various complaints and suggestions.

One of key challenges was the frequent system failure. The access to the M-PESA services is at times impossible. This was because of poor network reception, frequent power outages and overloaded Safaricom's central servers. Further, the respondents complained of slow service at peak times.

Security and fraud related activities were also identified as a challenge. The first was the security of the M-PESA money remittance message, which is usually not password protected. This meant that anybody who obtains possession of the phone could read the message and see all the financial transactions of the phone owner. This is a security and privacy risk and should be changed such that it can only be accessed by using the owner's password. It was not unusual for family members, roommates and work colleagues to have access to someone's phone, hence the need for protecting the M-PESA money remittance message.

The second security related challenge was sending money to the wrong recipient. The system did not have feedback to confirm that the number that the user had entered indeed belonged to the intended recipient. It was often a common mistake for an individual to send money to the wrong number by confusing one of the digits or sometimes names. This becomes more important when one also considers the relatively high level of illiteracy. Money sent to the wrong number was hard to recover 
unless the sender noticed immediately and alerted the service provider. The most common scenario, however, would be that the sender discovers the mistake much later and by then it is too late, as the wrong recipient will have already cashed the money.

Another key challenge was lack of "electronic float money" among most agents, limiting the amount tarders can receive at any one time. M-PESA transactions require the agent to exchange cash for electronic float money and vice versa. In an ideal situation, the money deposits and withdrawals should balance and therefore no problem would arise. However, the reality is that agents will face different "float" issues. In Limuru town, majority of the people send money to their rural folks, and this makes the agents run out of cash float. The agents will need to go to the nearest bank to deposit the surplus cash and wait until Safaricom verifies reception and sends the equivalent electronic float money to continue serving other clients.

\section{CONCLUSION AND IMPLICATIONS}

From the results above, it can be concluded that Mobile money transfer service mainly M-PESA is one of the factors that determines the success of business among other factors such as business capital investment, traders experience, education, business location, nature of the business and business budget. As a result, it is important that micro-businesses adapt the mobile money service in order to facilitate payment to creditors and also to receive payment from their debtors on time.

Though M-PESA is an intervention that has changed lives, some challenges still exist. Mainly challenges of electronic money float. Regarding the challenges of short hours of service, Safaricom have increased their hours of service to 24 hours of service. Furthermore, its partnership with PESA point, a third party ATM network in Kenya might address this problem. Further, Safaricom has partnered with banks so that M-PESA users are able to access to the bank ATM services where they can withdraw from their M-PESA accounts. However, security related to sending money to the wrong recipient still persists. This problem may need to be addressed from several fronts. First, the government and the mobile phone service providers are working together to enforce the registration of all individual's phone numbers. Secondly, the providers needs to update their system such that it gives feedback to users that the money was delivered to the intended recipient and displays delivery details in terms of phone number, time and location. Thirdly, a fast action mechanism needs to be implemented in case one sends money to the wrong number as well as remedial measures on money recovery. To minimize security issues the M-PESA service provider has introduced new SIM cards which enable the user to access his/her phonebook when sending money unlike in the past where the contacts were written separately and in the process a mistaken identity might be 'lucky' to receive the cash.

\section{REFERENCES}

Cracknell, D. (2004). Electronic banking for the poor-panacea, potential and pitfalls Small Enterprise Development, 15(4), 8-24.

Central bureau of statistics. National micro and small enterprise baseline survey, (2005)

Davies, F D (1989) "Perceived Usefulness, Perceived Ease of Use and User Acceptance of Information Technology". MIS Quarterly 13 (3), 319-339.

Economist (2009 c) "the power of mobile money" from the Economist Print edition. http://www.economist.com/special reports/24 sept $4^{\text {th }}$ dec 2011

Hughes N, Lonie S (2007). M-Pesa, Mobile Money for the Unbanked: Turning Cellphones into 24Hour Tellers in Kenya Innovation. Innovations: Technology, Governance, Globalization Magazine. 2: 1-2

Info DEV. (2006). Micro-payment systems and their application to mobile networks. RetrievedMay7,2008,fromhttp://infodev.org/files/3014_file_infoDev.Report_m_Commerce_Jan uary.2006.pdf m-banking Pre-publication draft. Edits possible. (C) 2008 Asian Media and Information Center 21

Ivatury, G. (2004). Harnessing technology to transform financial services for the poor. Small Enterprise Development, 15(4), 25-30.

Ivatury, G., \& Pickens, M. (2006). Mobile phone banking and low-income customers: Evidence from South Africa. Washington, DC: Consultative group to assist the poor (CGAP) and the United Nations Foundation. 
Jenkins, Beth. 2008. "Developing Mobile Money Ecosystems." Washington, DC: IFC and the Harvard Kennedy School.

Morawczynski, Olga \& Mark, P. (2009). Poor people using mobile financial services: observations on customer usage and impact of M-PESA. C-gap Briefhttp://www.cgap.org/p/site/c/1.9.36723/

Mallick A. 2004. Business development services, unemployment and the Kenya information sector <URL: Http//Fletcher.tuft.edu>.

Mugenda and Mugenda 2008. Social science research, theories and principles, Kijabe printing press, Kenya.

Mallat, N. (2007). Exploring consumer adoption of mobile payments - A qualitative study. Journal of Strategic Information Systems , 413-432.

Manica, L. \& Vescovi, M. (2009). Mobile Telephony in Kenya; is it Making the Life Better?http://www.it46.se/projects/UNITN_ict4sd/assignments/ICT4SD_manica_vescovi.pdf

Njenga, A. (2009). Mobile phone banking: Usage experiences in Kenya, unpublished MBA thesis of Catholic University of Eastern Africa

Omwansa T, (2009). M-PESA: progress and prospects, innovation case discussion

Porteous, D. (2006). "The Enabling Environment for Mobile Banking in Africa." Boston:

Porteous, D. (2007). Just how transformational is m-banking? Retrieved 10 January, 2008, http://www.finmarktrust.org.za/accessfrontier/Documents/transformational_mbanking.pdf

Safaricom (2009c) MPESA Key Performance Statistics. http://www.safaricom.co.ke/ fileadmin/template/main/images/MiscUploads/M-PESA\%20Statistics.pdf.

The Economist. (2006). Phoney finance. The Economist, 381, 87.

Venkatesh, V., Morris, M., Davis, G. \& Davis, F. (2003). User Acceptance of Information

Technology: Toward a Unified View, MIS Quarterly, 27, 3, 425-478.

Venkatesh, V. \& Davis, F. (2000). Determinants of Perceived Ease of Use: Integrating Control, Intrinsic Motivation, and Emotion into the Technology Acceptance Model, Information Systems Research, 11, 4, 342-365.

\section{AUTHORS' BIOGRAPHY}

Dr. Ann Kalei, is currently lecturing Business Management at Mt Kenya University, Eldoret Nairobi Kenya. She made contributions to this article when teaching MBA students at the Presbyterian University of East Africa. Her other research work is on Kenyan job market.

Dr. Hannah Wambugu, is currently lecturing Marketing Management at Kirinyaga University College, a constituent College of Jomo-Kenyatta University of Science and Technology in Nairobi, Kenya. She has written a lot about consumer behavior towards products/services from different industries in Kenya. Much of her research work can be found in reputable journals such as European Journal of Business and Management and International of Economics, Commerce and Management.

Mr Peter Githae, made his contributions to this article when he was doing his research project for his MBA at Presbyterian University of East Africa, Nairobi Kenya 